\author{
Aleksander Jagiełło \\ Chair of Transportation Market, Faculty of Economics, University of Gdańsk, Poland
}

\title{
THE POLISH ELECTRIC BUS MARKET AGAINST A BACKGROUND OF THE WORLD MARKET
}

\begin{abstract}
In the majority of the developed and in some of the developing countries we can observe gradual shift from the conventional public urban transport vehicles driven by diesel fuel towards electric vehicles. The process requires changes in the demand and supply side of urban transport market in particular countries around the world. The aim of this paper is to assess the standing of electric bus market in Poland against a background of the European and world market. The assessment involved presenting, in the first part of the article, characteristics of the worldwide and European markets from the demand and supply side. As for the world market of electric buses, the article discusses at great length the characteristics of Chinese market since this is the dominant market as regards both the number of vehicle in operation and the number of manufactured electric buses. The second part of the article provides the characteristics of demand and supply side of electric bus market in Poland presenting both domestic and European electric bus manufacturers who situated their production plants in Poland. The article also presents forecasts related to the scale of demand increase reported by the Polish local authorities.
\end{abstract}

Keywords: electric bus, electric bus market, electric bus manufacturers

\section{Introduction}

At present in Poland, the majority of buses used by urban transport operators are conventional buses with Diesel engines. As a result of amendments introduced in the Polish and European laws, the public urban transport began to shift from the conventional towards the alternative power sources, including electric energy. The introduction of vehicles powered by electric energy is regarded as grounds for sustainable mobility, environmental protection and energy diversification. 
According to the report provided by the European Environment Agency, 6 out of 10 cities with the most polluted air in Europe are located in Poland. The information has been confirmed in "Global Urban Ambient Air Pollution Database 2016" report published by the World Health Organization indicating that 33 out of 50 most polluted European cities are cities located in Poland. As a result of persistent pollution of Polish cities reaching levels which endanger the health of their inhabitants, the cities are particularly predestined to have the zero-emission electric vehicles introduced as soon as possible.

The data presented in fig.1 depicting forecast developed in ZeEUS "Zero Emission Urban Bus System" project indicates that within two years, until 2020, the number of conventional city buses with Diesel engines will be reduced to 53\% in Europe. In 2030, electric energy will become the dominant drive system for city buses (with $90 \%$ share of alternative power sources for city buses).

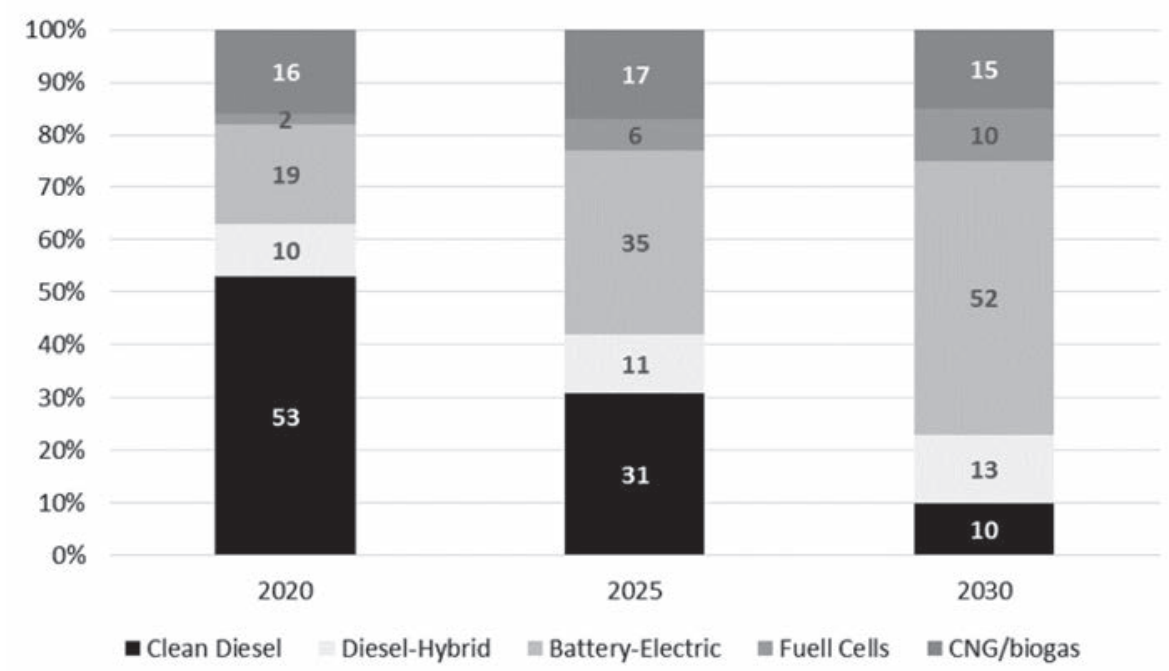

Figure 1. Forecast for the development of city bus market in Europe between 2020 and 2030 [\%] Source: (Zeeus.eu, 2018)

In order to enable the development of Polish fleet of public transport vehicles powered by electric energy and to meet the objectives of e.g. the White Paper and the act on electromobility and alternative fuels, the development of electric bus market supply side is necessary. The development must occur among the manufacturers of vehicles, loading infrastructure and battery storage. Under the assumptions of e-bus program, thanks to the stimulation of the supply and demand side of electric vehicle market in Poland, 1000 e-buses should be put into operation until 2023. 


\section{Electric Bus World Market}

Geographically, the world's largest electric bus market is the Chinese market. Between 2011 and 2017 in China, nearly 317 thousand electric buses were purchased and put into operation (Dixon, 2018). It is estimated that at the end of 2015, the Chinese fleet of electric buses with ca. 170 thousand vehicles constituted ca. 98\% of all e-buses operating in the world (Ayre, 2017). In 2016 alone, China put into operation 115700 electric buses (Figure 1), i.e. ca. 180 times more than the entire Europe (fall in 2017 was caused by the cessation of subsidies). It is also estimated that China is responsible for $75 \%$ of the world's production of batteries used for public urban transport (Dodgson, 2016).

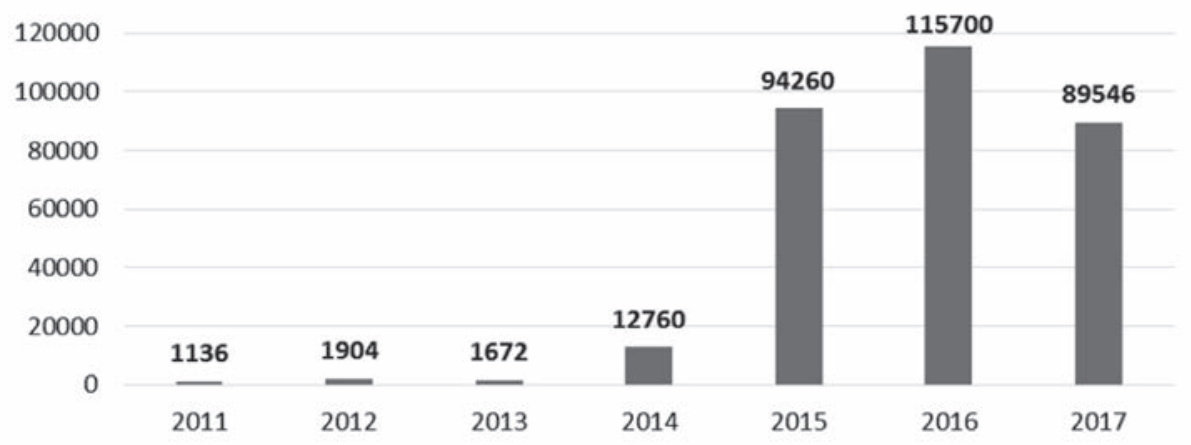

Figure 2 Sale of electric buses in China between 2011 and 2017 Source: (Dixon, 2018)

Such dynamic development of the Chinese electric bus market was possible thanks to the policy of the Chinese central and local authorities aiming at total electrification of buses in the largest cities (Beijing is planning to increase the number of electric buses from the current one thousand to 10 thousand buses until 2020) (Xinhuanet.com, 2017). In the Chinese city of Shenzhen inhabited by 12 million people, selected in 2009 as one of 13 pilot cities in the "new-energy" national program, 100\% of operating vehicles are electric buses. At present, 16359 buses operating on a regular basis are buses powered by electricity. It means that the city of Shenzhen uses more electric buses than all buses (both conventional with Diesel engines and buses powered by alternative energy sources) used in 5 cities of North America with the largest number of fleet (New York: 5773 vehicles, Los Angeles: 2328 vehicles, New Jersey: 2212 vehicles, Chicago: 2164 vehicles, Toronto: 1926 vehicles) (Hanley, 2018). The fleet of electric buses operating in the city of Shenzhen is also 30\% higher than the whole fleet of city buses operating in Poland. It is estimated that as a result of replacing conventional buses with electric ones, in the city of Shenzhen, $\mathrm{CO} 2$ emission was reduced by 1.35 million tons and fuel consumption by 345 thousand tons of diesel fuel, which represents 366 thousand tons of coal (electric buses in the city of Shenzhen consume $72.9 \%$ less energy compared to conventional buses thanks to higher efficiency of electric engines compared to conventional ones) (Ximin, 2017). For comparison, the largest fleet 
of electric buses in Europe (these are hybrid buses with $70 \%$ of the route powered by electricity) belongs to the Belgian public transport operator TEC Group rendering services in the city of Charleroi and Namur. The fleet comprises 101 Volvo 7900 Electric Hybrid buses (Volvogroup.com, 2017). The dominant position of China on the electric bus world market is reflected by data presented in Figure 3. It proves that the Chinese market demand for electric buses constitutes ca. $80 \%$ of the global demand of electric vehicle sector for traction batteries.

China electric buses

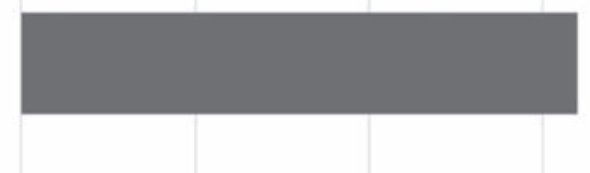

Global electric vehicles

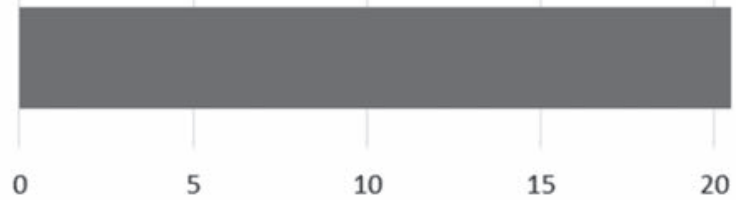

25

Figure 3. Total demand for batteries (GWh)

Source: (Bullard, 2017)

Among numerous factors which contributed to rapid development of electric bus market in China, the most important include (Bullard, 2017):

- government support provided through the national and regional subsidies which brought the electric bus purchase cost to the same level as the purchase cost of conventional bus (despite twofold higher market price of electric buses compared to the conventional ones),

- air pollution in cities endangering the health of inhabitants,

- policy aiming at reducing the import of fossil fuels,

- lack of urban transport systems in many cities before the introduction of electric buses, as a result of which there was no need to adjust the infrastructure and fleet-related investments to the existing, conventional urban transport systems,

- possibility to complete the infrastructure and fleet-related investments without the need to adjust them to the existing, conventional urban transport systems since no transport systems existed in many Chinese cities,

- national industrial policy aiming at developing the automotive and battery industry.

The largest electric bus manufacturer in the world is the Chinese company, Yutong. Their share in the Chinese market grew from $23.4 \%$ in 2016 to $28.7 \%$ in 2017. In 2017, compared to the previous year we observed the increase in market share of the second largest electric bus manufacturer in the world, BYD company, from $11.6 \%$ to $14.7 \%$ (Table 1). It contributed to the increase in the Chinese electric bus market concentration ratio CR3 from $47.3 \%$ in 2016 to $52.8 \%$ in 2017. Taking into 
account the dominant position of the Chinese electric bus market in the world market it means that three largest Chinese manufacturers are responsible for nearly half of the world's electric bus production.

Table 1. The top largest manufacturers of electric buses in China

\begin{tabular}{|l|l|c|c|c|c|}
\hline Ranking & Enterprises & Sales in 2016 & Sales in 2017 & $\begin{array}{c}\text { Market share } \\
2016\end{array}$ & $\begin{array}{c}\text { Market share } \\
2017\end{array}$ \\
\hline 1 & Yutong & 26859 & 24857 & $23.40 \%$ & $28.65 \%$ \\
\hline 2 & BYD & 13278 & 12777 & $11.57 \%$ & $14.73 \%$ \\
\hline 3 & Zhongtong & 14105 & 8167 & $12.29 \%$ & $9.41 \%$ \\
\hline 4 & CRRC & 4277 & 6328 & $3.73 \%$ & $7.29 \%$ \\
\hline 5 & Sunlong & 1397 & 4702 & $1.22 \%$ & $5.42 \%$ \\
\hline 6 & BAIC Foton & 6754 & 4139 & $5.88 \%$ & $4.77 \%$ \\
\hline 7 & Golden Dragon & 5272 & 3887 & $4.59 \%$ & $4.48 \%$ \\
\hline 8 & Nanjing King & 4466 & 3842 & $3.89 \%$ & $4.43 \%$ \\
\hline 9 & Long & & & & $3.50 \%$ \\
\hline 10 & Xiamen King & 3590 & 3033 & $3.13 \%$ & $2.94 \%$ \\
\hline & Long & 4950 & 2554 & $4.31 \%$ & $85.62 \%$ \\
\hline
\end{tabular}

Source: (Chinabuses.org, 2018)

Strong market position of BYD company on the domestic Chinese market allowed for its global expansion. At present, BYD production plants are located e.g. in France (Beauvais), USA (Lancaster), Brazil (Campinas) and Hungary (Komarom). The global expansion of BYD company occurs also through cooperation with companies operating on foreign markets, e.g. Smart Dreams company operating in India and ADL company operating in UK. As a result of entering foreign markets it is predicted that BYD company will become the largest electric bus manufacturer in the world (outstripping Yutong company) within the next few years. It is projected that BYD company production plants in the USA alone can manufacture 1500 electric buses annually, which constitutes $30 \%$ of the US market (Zhu, 2017). BYD company is one of around 30 large Chinese electric bus manufacturers who trying to gain market share in Europe and North America.

It is estimated that in 2016, 1273 electric buses were in operation across Europe (it means the increase of over 100\% in the number of electric vehicles in Europe compared to 2015) (Zeeus.eu, 2018). Today, Great Britain has the largest fleet of electric buses in Europe (17\% of all electric buses in Europe), the second largest fleet of buses powered by electricity belongs to the Netherlands (14\%), Poland, France, Germany and Italy each have $8 \%$ of the European fleet of electric buses (Zeeus.eu, 2018). So far the European electric bus market has been developing slowly compared to the Asian and Pacific countries. The main reasons for such situation involve:

- higher price of electric vehicles compared to conventional vehicles,

- lack of single European transport policy, with electrification of public transport as top priority, 
- lack of adjustment of the European countries existing electric grid to the needs of urban transport powered by electricity,

- lack of adjustment of laws to the requirements regarding the constriction of charging stations,

- lack of standardization of technological solutions regarding electric vehicle charging systems (today there are numerous incompatible charging systems),

- lack of conviction among fleet manufacturers that using electric energy to power city buses is well-grounded (Mercedes Benz and MAN, two of the largest city bus manufacturers in Europe are planning to start the production of electric buses only in 2018 and 2019, respectively).

The electric bus market in the USA, as in Europe, has been at its early stage of development. In 2016, in the USA ca. 200 electric buses were purchased, most of which operating in California (The Agility Effect, 2018). The largest American electric city bus manufacturer is Proterra company with its production capacity of 500 vehicles annually. It is estimated that in 2017 , the company manufactured $5 \%$ of all city buses put into operation in the USA, increasing thereby the number of produced buses by threefold compared to the previous year (Mitchell, 2018). Despite the fact that Proterra is regarded the largest American electric bus manufacturer in the USA, the company made its market debut in 2004 and till 2017 they sold ca. 400 vehicles used in 20 states (Muoio, 2018).

\section{Polish Electric Bus Market}

At present, Poland is one of the key automobile manufacturers in the Central and Eastern Europe, producing passenger cars, heavy vehicles and buses as well as automotive components and spare parts. In 2016, in Poland ca. 5.2 thousand buses were manufactured, within all segments, i.e. city buses, inter-urban, school and tourist buses (Figure 4). In the analysed period, between 2000 and 2016, higher production was recorded only twice between 2005 and 2006, i.e. before the world economic crisis in 2008.

In Poland buses are manufactured by:

- AMZ Kutno

- Autosan

- Kapena

- Man Bus

- Scania

- Solaris Bus \& Coach

- Ursus Bus

- Volvo Bus

Among them, three domestic companies (Solaris, Ursus, Solbus) and three European companies have in their offer or in the nearest future plan to include in their offer electric buses (excluding manufacturers offering electric mini-buses below 3.5t). 


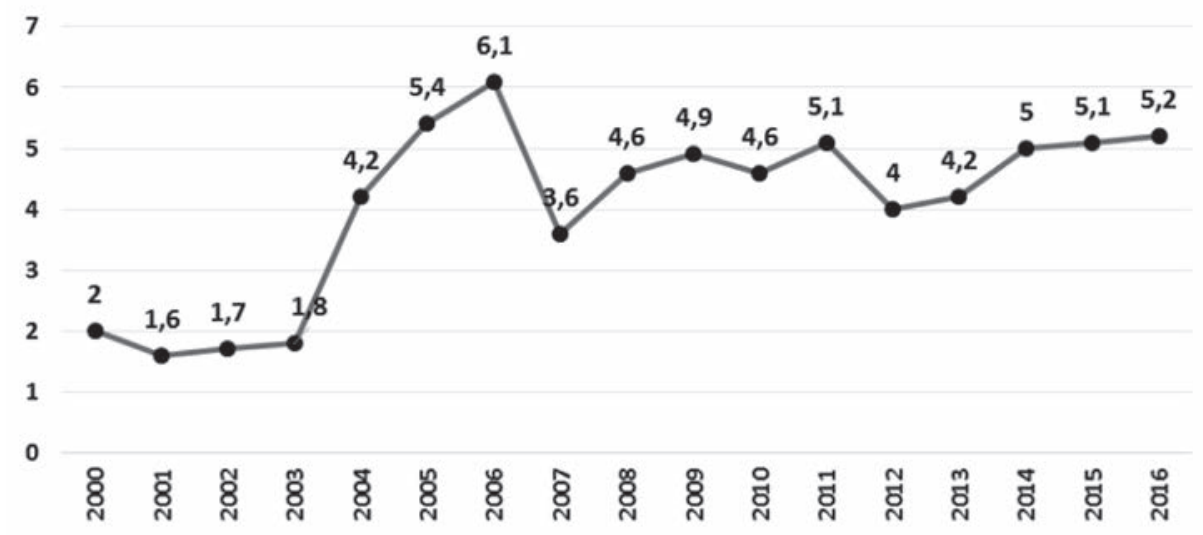

Figure 4. Production of buses in Poland between 2000 and 2015 [thou. of vehicles] Data includes vehicles for carrying 10 and more people.

Source: (own elaboration based on: Rozkrut, 2017)

At present, all companies manufacturing electric buses have in their offer 12 -metre vehicles. These days, such buses are the most popular, with nearly $80 \%$ share in the European fleet of electric buses (Figure 5). Today in Poland two companies (Solaris and Ursus) manufacture electric articulated buses (Table 2).

Table 2. Electric bus manufacturers in Poland

\begin{tabular}{|l|l|c|}
\hline \multicolumn{1}{|c|}{ Brand } & \multicolumn{1}{|c|}{ Number of offered electric bus types } & $\begin{array}{c}\text { Electric bus date of display/ } \\
\text { beginning of production }\end{array}$ \\
\hline Autosan & 1-12 m Autosan Sancity & 2017 \\
\hline MAN & $\begin{array}{l}-18 \mathrm{~m} \text { (presented at the trade fair in 2016) } \\
\text { Presentation of subsequent models is planned for 2018 }\end{array}$ & Production planned for 2019 \\
\hline Scania & $1-12 \mathrm{~m}$ Scania Citywide & 2017 \\
\hline Solaris & 3-8.9 m, 12 m, 18 m Solaris Urbino electric & 2011 \\
\hline Ursus & $\begin{array}{l}\text { 5-8.5 m, 10 m }, 12 \mathrm{~m}, 18 \mathrm{~m} \text { Ursus Bus City Smile, } \\
12 \mathrm{~m} \text { Ursus Bus Ekovolt }\end{array}$ & 2013 \\
\hline Volvo & $1-12 \mathrm{~m}-$ Volvo 7900 Electric & 2016 \\
\hline
\end{tabular}

Source: (own elaboration)

Between 2015 and 2017 in Poland, 137 electric buses were manufactured, with 82 in 2017 alone (28\% for export). Despite the increase in production volume recorded year to year, the whole production of electric buses in Poland in 2017 constituted less than $0.5 \%$ of production generated by the largest electric bus manufacturer in the world. It is forecasted that in 2018 the Polish production plants will manufacture ca. 270 electric buses (Mpit.gov.pl, 2018), which would mean growth of the Polish electric bus market by 330\% compared to 2017 and strengthening the position of Polish electric bus manufacturers on the European market. 


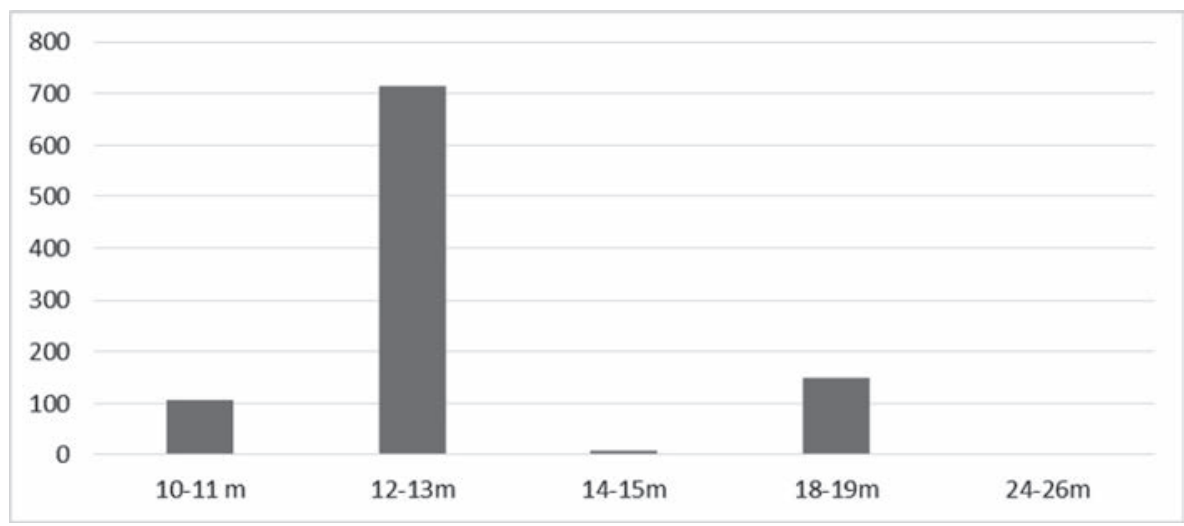

Figure 5. Distribution of European urban electric bus models, by vehicle length Source: (Zeeus.eu, 2018)

Table 3. Production of electric buses in Poland between 2015 and 2017

\begin{tabular}{|l|c|c|c|}
\hline \multicolumn{1}{|c|}{ Producer } & 2015 & 2016 & 2017 \\
\hline Solaris & 25 & 28 & 63 \\
\hline Ursus & 0 & 1 & 14 \\
\hline Volvo & 0 & 1 & 5 \\
\hline Total production & 25 & 30 & 82 \\
\hline
\end{tabular}

Source: (Mpit.gov.pl, 2018)

In Poland, as in Great Britain, France, the Netherlands, Germany and Italy, legislation is introduced aiming at providing legal framework and incentives for further development of electromobility in urban transport. One of the objectives of the currently introduced flagship program, e-Bus, a part of the Strategy for Responsible Development supported e.g. by the Polish Development Fund, involves „introducing the requirement for providing proper fleet structure $(20 \%$ of fleet should include zero-emission vehicles) by companies rendering urban transport services". The data presented in table 16 proves that between 2015 and 2017, on average 111 buses with alternative drive system were registered annually (including vehicles powered by gas and electricity, and hybrid vehicles). Most of (150 vehicles) the registered new buses with alternative drive system were CNG or LNG driven buses, 98 were hybrid vehicles, whereas the least numerous were fully electric vehicles in the number of 85 .

Table 4. Number of registered city buses with alternative drive system in Poland between 2015 and 2017

\begin{tabular}{|l|c|c|c|}
\hline \multicolumn{1}{|c|}{ Type of drive } & 2015 & 2016 & 2017 \\
\hline CNG or LNG & 119 & 19 & 12 \\
\hline Hybrid & - & 17 & 81 \\
\hline Electric & 16 & 6 & 63 \\
\hline Total & 135 & 42 & 156 \\
\hline
\end{tabular}

Source: (own elaboration based on: Infobus.pl, 2018 and Infobus.pl, 2016) 
In the analysed period, between 2015 and 2017, buses with alternative drive system constituted on average $13.8 \%$ of all registered city buses. Buses powered by electricity representing $25 \%$ of new, first time registered buses with alternative drive system constituted, in the analysed period, nearly $4 \%(3.7 \%)$ of all city buses put into operation and $1.3 \%$ of all buses. The trend related to vehicle fleet electrification and use of other alternative drive systems can be observed only in the sector of city buses. Other sectors (tourist and inter-urban buses and minibuses) still rely on only conventional drive system (Diesel engine).

\section{Conclusions}

The demand as well as the supply side of electric bus world market is dominated by China. In Europe, the process of shifting from conventional buses to buses powered by electricity has only begun, although there are strong indications that the process will accelerate when more countries and local authorities take decision to limit the impact of public transport on the health and quality of life of city inhabitants.

Although the Polish electric bus market constitutes a small part of the world market as regards the reported demand and supply of vehicles, it is an important part of the European market. It is proved by:

- eight-percent share in the European fleet of electric buses,

- six electric bus manufacturers on the European market,

- growing demand for electric buses, the cumulative value of which as per the assumptions of e-bus program in 2023 should amount to 1000 vehicles,

- growing supply related to new models of electric buses scheduled for production and expansion of Polish manufacturers into other European markets.

Consequently, the ongoing electrification of urban transport fleet observed in Poland, Europe and around the world constitutes an opportunity for further development of the Polish automobile market and Polish electric bus manufacturers.

\section{References}

Ayre, J. (2017). China 100\% Electric Bus Sales Grew To 115,700 In 2016 | CleanTechnica. Available from https://cleantechnica.com/2017/02/03/china-100-electric-bus-sale s-grew-115700-2016/ [Accessed 22 February 2018].

Bullard, M. (2017), China Goes All In on the Transit Revolution. Available from https:// www.bloomberg.com/view/articles/2017-12-08/china-goes-all-in-on-the-transit-revolution [Accessed 22 February 2018].

Bullard, M. (2017). China Goes All In on the Transit Revolution. Available from https:// www.bloomberg.com/view/articles/2017-12-08/china-goes-all-in-on-the-transit-revolution [Accessed 22 February 2018].

Chinabuses.org. (2018). CRRC New Energy Bus Sales Grew 47.95\% in 2017-news-. Available from http://www.chinabuses.org/news/2018/0122/article_11426.html [Accessed 22 February 2018].

Dixon, T. (2018), China 100\% Electric Bus Sales Drop To 89,546. Available from https:// evobsession.com/china-100-electric-bus-sales-drop-to-89546-in-2017/ [Accessed 22 February 2018]. 
Dodgson, L. (2016), Buses and batteries: a rising sector - Power Technology. Available from https://www.power-technology.com/features/featurebuses-and-batteries-a-rising-sector-4904956/ [Accessed 22 February 2018].

Hanley, S. (2018),Shenzhen Completes Switch To Fully Electric Bus Fleet. Electric Taxis Are Next. Available from https://cleantechnica.com/2018/01/01/shenzhen-completes-switch-fully-electric-bus-fleet-electric-taxis-next/ [Accessed 22 February 2018].

Infobus.pl. (2016). Polski rynek nowych autobusów w 2015 r. Available from http://www. infobus.pl/polski-rynek-nowych-autobusow-w-2015-r-_more_80918.html [Accessed 22 February 2018].

Infobus.pl. (2018), Polski rynek nowych autobusów - 2017 rok. Available from http://infobus. pl/polski-rynek-nowych-autobusow-2017-rok-_more_102133.html [Accessed 22 February 2018].

Mitchell, A. (2018), Proterra electric buses experience surge of interest as cities invest in clean transit. Available from https://www.greenvilleonline.com/story/money/2018/02/17/ proterra-electric-buses-experience-surge-interest-cities-invest-clean-transit/1025854001/ [Accessed 22 February 2018].

Mpit.gov.pl. (2018), Program E-bus: Polski Autobus Elektryczny - Ministerstwo Przedsiębiorczości i Technologii. Available from https://www.mpit.gov.pl/strony/strategiana-rzecz-odpowiedzialnego-rozwoju/kluczowe-projekty/program-e-bus-polski-autobu s-elektryczny/ [Accessed 22 February2018].

Muoio, D. (2018), A tiny startup is quietly trying to become the Tesla of buses. Available from http://www.businessinsider.com/proterra-electric-bus-maker-expands-raises-140-million2017-2?IR=T [Accessed 22 February 2018].

Rozkrut, D. (Ed.) (2017), Rocznik Statystyczny Przemysłu 2017, Zakład Wydawnictw Statystycznych, Warszawa.

The Agility Effect (2018), All-electric buses set to conquer the world. Available from https:// www.theagilityeffect.com/en/article/electric-buses-set-conquer-world/ [Accessed 22 February 2018].

Volvogroup.com. (2017). Volvo Buses receives order for 90 electric buses from Belgium. Available from http:/www.volvogroup.com/en-en/news/2017/feb/news-2451717.html [Accessed 22 February 2018].

Ximin, H. (2017), All Shenzhen public buses now electric Mp.weixin.qq.com. Available from https://mp.weixin.qq.com/s? _biz=MzIyMzMzNjE3NA $==\& \operatorname{mid}=2247489746 \& i d x-$ $=1 \& s n=a 8 b b 0210 f 150 a 93 d 80718 a 202018 \mathrm{~d} 42 \mathrm{f} \& \mathrm{chksm}=\mathrm{e} 81 \mathrm{e} 9 \mathrm{~b} 53 \mathrm{df} 6912452 \mathrm{e} 156066766 \mathrm{e}-$ 8b8eaf8fc9107033b46df16eed95b538609ac0b8dee55feb\&mpshare $=1 \&$ scene $=1 \&$ srcid=1228DNpV2EJVJ81zBrr0yjzT\#\% 23 [Accessed 22 February 2018].

Xinhuanet.com. (2017), Beijing's electric buses to number 10,000 by 2020 - Xinhua | English. news.cn. Available from http://www.xinhuanet.com/english/2017-08/02/c_136493850.htm [Accessed 22 February 2018].

Zeeus.eu. (2018). Available from http://zeeus.eu/uploads/publications/documents/zeeus-ebusreport-2.pdf [Accessed 22 February 2018], pp. 10, 12, 14, 18.

Zhu, L. (2017), BYD chases 30\% of e-bus market in North America - Business. Available from http://www.chinadaily.com.cn/business/motoring/2017-10/12/content_33147194. htm [Accessed 22 February 2018].

\section{Corresponding author}

Aleksander Jagiełło can be contacted at: a.jagiello@ug.edu.pl 